\title{
Fissurectomy Combined with High Dose Botulinum Toxin is a Safe and Effective Treatment for Chronic Anal Fissure and a Promising Alternative to Surgical Sphincterotomy
}

\section{Thomas G Barnes, Zakhi Zafrani, Ayman S Abdelrazeq. Warrington \& Halton Hospitals NHS Foundation Trust, UK}

\section{Abstract}

\section{Background}

There is paucity of data on the long-term outcome of the combination of fissurectomy and botulinum toxin A (BTA) injection for the management of chronic anal fissure (CAF).

\section{Objectives}

To assess the safety, efficacy and long-term outcome of the combination of fissurectomy and BTA injection.

\section{Design}

A non-randomised prospective cohort study.

\section{Settings}

A district general hospital in the United Kingdom.

\section{Patients}

The cohort included all patients treated with fissurectomy and Botulinum Toxin A for chronic anal fissure between September 2008 and March 2012.

\section{Intervention}

The combination of fissurectomy and Botulinum Toxin A injection.

\section{Main outcome measures}

Symptomatic relief, fissure healing, complications, recurrence and the need for further surgical intervention.

\section{Results}

One-hundred-and-two patients received fissurectomy and Botulinum Toxin A injection for chronic anal fissure. At 12-week follow-up 68 patient had resolution of symptoms and complete healing of chronic anal fissure, 29 patients had improvement of symptoms but incomplete healing and had further topical or Botulinum Toxin A treatment with subsequent complete healing.

Ninety-five patients (93\%) reported no post-operative complications. Seven patients reported a degree of incontinence in the immediate post-operative period. All reported normal 
continence at12-week follow-up. No local complications were observed or reported. At mean follow up of 33 months there was no evidence of recurrence. 12-month follow up was conducted via telephone interview only.

\section{Limitations}

The study is non-randomised and has not examined dose response of botox dose.

\section{Conclusions}

Fissurectomy combined with high dose Botulinum Toxin A is a safe, effective and durable option for the management of chronic anal fissure and a promising alternative to surgical sphincterotomy.

Key Words: anal fissure; fissurectomy; botulinum toxin. 


\section{$\underline{\text { Introduction }}$}

Anal fissures a common problem causing significant symptoms in a mostly young population. ${ }^{1}$ Most commonly they occur in the posterior midline but can occur in other locations. ${ }^{2}$ Most acute fissures heal spontaneously or by simple measures including dietary modification, increasing fluid intake and stool softeners. However, some progress to form a chronic fissure and show resistance to heal without further intervention. Although there is no strict temporal definition of chronicity, it is suggested that any patient with symptoms for more than 8 weeks will usually have a chronic fissure. ${ }^{3}$

Most current medical and surgical therapies aim to break the cycle of anal pain and spasm by reducing the maximum resting pressure of the internal anal sphincter resulting in an increase in mucosal blood flow and promotion of healing. ${ }^{1,4}$ Pharmacological topical therapies, including glyceryltrinitrate (GTN), and calcium channel blockers, such as diltiazem, have been shown to be marginally better than placebo but can be associated with troublesome side effects, headache being one of the most common. ${ }^{5,6}$

The gold standard surgical treatment for $\mathrm{CAF}$ has been partial lateral internal sphincterotomy (PLIS). ${ }^{6,7}$ Whilst the success rate of this procedure can be over $95 \%$, there is concern over the risk of disturbance in the continence mechanism. ${ }^{8,9}$

Due to the short and long-term risk of incontinence associated with PLIS, botulinum toxin A (BTA) has become an increasingly popular second line therapy in the management of CAF prior to committing to a PLIS. ${ }^{10}$

BTA alone has been shown to have slightly better results than topical therapy. ${ }^{10}$ It is safe and well tolerated but is associated with a high long-term recurrence rate. ${ }^{10}$ Recent reports suggest that a combination of fissurectomy and BTA, in the management of CAF, is more effective than BTA alone. ${ }^{3,11-17}$

It is our routine practice to offer all patients who have failed topical therapy for CAF or those who present with signs of chronicity, a combination of fissurectomy and high dose (100U) BTA injection.

In this study, we aimed to determine the efficacy, safety and durability of using a combination of fissurectomy and BTA in the management of CAF and further add to the data on this approach.

\section{Methods}

All patients treated by a combination of fissurectomy and BTA injection between September 2008 and March 2012 were included in the study. The patients were under the care of a single 
surgeon (ASA) at Warrington and Halton Hospitals NHS Foundation Trust. All patients were counselled thoroughly regarding the natural history of anal fissure, available medical and surgical options, and the benefits and risks associated with each modality. All enrolled patients gave their informed consent. This study was registered with the local Research and Audit Department in Warrington and Halton NHS Foundation Trust. Patient's data was collected prospectively.

The diagnosis of CAF was based on the presence of any features of chronicity; a sentinel tag at the distal pole of the fissure, a hypertrophied anal papilla at its proximal extent, a fibrotic edge and the appearance of the circular fibres of the internal sphincter muscle in its base, and/or symptoms persistent for more than eight weeks despite topical treatment with GTN or diltiazem. Patients with acute fissures were not included in this study.

Patients were excluded if their fissure(s) were associated with other pathology (inflammatory bowel disease, cancer, peri-anal abscess, III/IV haemorrhoids). Patients who had previous anal surgery, coexisting medical conditions requiring calcium channel blockers or nitrates as well as patients who had contraindications to BTA, were also excluded.

Baseline data was collected including: age, sex, body mass index (BMI), duration of symptoms, location of fissure, and continence status. Continence was assessed using the Cleveland Clinic Faecal Incontinence Scoring System (CCFIS). ${ }^{18}$

All patients were treated using the same method. Metronidazole was administered intravenously in a dose of $500 \mathrm{mg}$ on induction of anaesthesia. Patients were placed in the Lloyd-Davis position and an examination under anaesthesia (EUA) of the anorectum was performed. Diagnosis of CAF was confirmed and fissurectomy performed by excision of the fibrotic edge of the fissure, curettage of its base, and diathermy excision of the sentinel skin tag and/or anal papilla if present. To avoid unintended sphincteric damage the curettage of the fissure base was performed gently and anal speculums were not used. A total dose of 100 units of BTA (BOTOX; Allergan, Marlow, Buckinghamshire, UK) was diluted in $1 \mathrm{ml}$ of isotonic saline. The solution was injected directly into the internal sphincter at the fissure(s) base under vision using a 26 gauge needle. Local anaesthesia with $20 \mathrm{mls}$ of $0.5 \%$ Bupivacaine was infiltrated into the fissure area. For patients with a single fissure all 100 units were injected into the fissure base, where multiple fissures were observed the dose was divided equally between the sites.

The procedure was performed as a day-case and all patients were prescribed a seven-day course of non-opioid analgesics as required with an eight-week supply of a bulk forming laxative (Fybogel, 1 sachet twice daily). Patients were advised to take regular warm Sitz baths, to maintain a high fibre diet and to increase their fluid intake.

All patients were evaluated in the outpatient clinic approximately 12 weeks following their procedure. Specific outcomes assessed included: resolution, improvement or persistence of symptoms; healing (defined as complete epithelialisation of the fissure area) or persistence of 
fissure(s); and complications in the post-operative period. Continence status was reassessed using the Cleveland Clinic Faecal Incontinence Score. Patients who were asymptomatic with complete fissure healing were provided with dietary advice, reassured and discharged. Those with a persistent fissure were offered further treatment with either topical diltiazem $2 \%$ (Anoheal; SLA Pharma, Watford, UK), repeat BTA injection +/- fissurectomy, lateral sphincterotomy (if appropriate), or referred to a tertiary centre for consideration of an anal advancement flap. Re-treated patients were then evaluated using the same protocol.

All patients were contacted 12-month post-operatively, via telephone, and asked whether they had any recurrence of anal fissure symptoms (post-defecation pain and/or bleeding), or if they sought any medical advice relating to anal fissure post discharge. Their continence status was again reassessed using the Cleveland Clinic Faecal Incontinence Score.

Irrespective of the scheduled clinic appointments, patients were given a telephone number and an email address and encouraged to contact the senior author's office if they encountered any symptoms and were seen promptly on request.

Clinical records of all recruited patients were reviewed in March 2013. These were analysed for any evidence of the recurrence of anal fissure. Comparison of fissure healing between various groups was evaluated using Fisher's exact test.

\section{$\underline{\text { Results }}$}

A total of 105 patients fulfilled the inclusion criteria, however 3 from the outset declined Botox and opted for surgical sphincterotomy and were therefore excluded leaving 102 patients to be included in this study, of which 62 were female. The follow-up period ranged from 12-54 months (mean 33 months) (Table 1).

Mean age was 41 years (range 21-70) and mean BMI of 27 (range 16-45). The majority of patients had a posterior fissure $(70.6 \%, 72$ patients). Two fissures were present both anteriorly and posteriorly in 23 patients $(22.5 \%)$ and 7 had anterior fissures $(6.7 \%)$. Indications for fissurectomy and BTA were CAF symptoms that failed to respond to topical therapy 41 patients $(40.2 \%)$, CAF with signs of chronicity 27 patients $(26.5 \%)$ or both 34 patients $(33.3 \%)$. Pre-operatively all patients were fully continent with a CCFIS of 0.

At 12-week post-operative review, 97 patients (95\%) showed resolution or improvement of symptoms. Of these 97 patients, 68 reported resolution of their symptoms, complete fissure healing was observed, and they were discharged. Of the remaining 29 patients where symptoms had improved but fissure healing was incomplete, 25 were prescribed topical diltiazem 2\% and Fybogel for 8 weeks. Four patients declined topical therapy opting for repeat treatment with BTA +/- fissurectomy, if signs of chronicity were found. No recurrence of CAF signs of chronicity was observed therefore no fissurectomy was required. Fissures in 
all 29 patients had subsequently healed and the patients were then discharged following their 12-week postoperative assessment.

The five patients with no improvement included three males, one female with a posterior anal fissure and one female with an anterior anal fissure. These patients declined a repeat fissurectomy and BTA injection opting for alternative surgery. Four had a PLIS and one (a 35 year old female gravida 4 para 4 with low sphincter pressure on anorectal physiology testing) was referred to a tertiary care centre where she underwent an anal advancement flap. The fissure in all 5 patients had completely healed at 12-week post-operative review. (Figure 1)

\section{Post-operative Complications}

Ninety-five patients (93\%) reported no post-operative complications. Seven patients reported a degree of incontinence in the immediate post-operative period: 4 to liquid stool and flatus (CCFIS = 2, 3, 4 and 4) and 3 to flatus alone (CCFIS = 2, 2 and 3). All patients returned to normal continence at 12 -week follow-up $(\mathrm{CCFIS}=0)$. No local complications including bleeding, perianal sepsis, thrombosis or haematoma were observed or reported. We did not observe any keyhole deformity at the fissurectomy site in any of our patients.

At 12-month telephone interview, all patients were asymptomatic with normal continence and no evidence of recurrence of their previously treated anal fissure. Clinical records for all patients were reviewed in March 2013, equating to a follow-up period ranging between 12-54 months (mean 33 months) (Table 1). Again, no patients had anal fissure related complaints or had received anal fissure related treatment, since being discharged.

We observed no significant difference in fissure healing between posterior and anterior anal fissures (95\% vs. $86 \%$ ), $\mathrm{p}=0.38$. Similarly there was no difference between males and females (97\% vs. $93 \%), \mathrm{p}=0.38$.

\section{$\underline{\text { Discussion }}$}

Partial lateral internal sphincterotomy is still considered to be the "gold standard" treatment for CAF. Although PLIS is highly effective, permanently curative in $95 \%$ of cases and with a high patient satisfaction, the post procedure impairment of continence is not uncommon. ${ }^{1 \text {, }}$ ${ }^{8}$ The incontinence incidence varies between $0-35 \%$ for flatus, $0-21 \%$ for liquid stool and 0 $5 \%$ for solid stool. ${ }^{8}$ Garg et al., conducted a meta-analysis of patients having PLIS with a follow-up period ranging from 24-124 months. Their study showed an overall continence disturbance rate of $14 \% .{ }^{19}$ In addition to this, there is an incidence of $1 \%$ of wound infection and fistula formation and $5 \%$ of delayed wound healing. ${ }^{20}$

It is a common belief that the reported incontinence following PLIS is mainly to flatus and mostly transient, and the risk of permanent incontinence is about $1 \% .{ }^{15}$ Even if patients were to remain continent in the short-term following PLIS, muscle disruption is permanent. 
Patients would be at an increased risk of suffering with incontinence in later life as resting sphincter pressure decreases with age. ${ }^{21}$ Furthermore, the possibility of future anorectal surgery, radiation therapy, or obstetric trauma dictates that the risk of incontinence after PLIS should be considered lifelong to an often young, otherwise healthy person. ${ }^{15}$ Moreover, anal deformity, surgical site infection and fistula at the site of the sphincterotomy are wellrecognised complications.

Due to the aforementioned risks, the need to explore an alternative to PLIS, is compelling. Fissurectomy or BTA are among those alternatives.

Fissurectomy alone has been advocated in children or in patients perceived to be at a higher risk of developing incontinence. ${ }^{22,23}$ It enhances healing by removing the fibrotic fissure edges, unhealthy granulation tissue at the base, and the sentinel skin tag when present creating in essence an acute fissure. ${ }^{3}$ However, as it does not address the anal sphincter hypertonicity, it carries a lower success rate and a higher recurrence rate compared to PLIS. 24

BTA injection alone can promote healing of fissures and symptomatic relief, but does not address the signs of chronicity. Complete resolution of fissures occurs in less than $50 \%$ of patients treated with BTA alone. ${ }^{11,25}$ A combination of both fissurectomy and BTA can address both elements of CAF, (chronic fibrosis and internal sphincter hypertonicity) and appears to be a plausible alternative to PLIS.

There is a paucity of data on the long-term outcome of combining fissurectomy and BTA. Table 2 summarises the published literature to date. ${ }^{3,11-17}$ There is a clear variation in the cohorts of patients included, the dose of BTA utilised, the site of BTA injection and the duration of follow-up. Witte et al., used Dysport whilst all other studies used Botox. ${ }^{14}$ They primarily closed the excised fissure site and used fissurectomy and BTA only when symptoms persisted after a minimum of 2 BTA injections. ${ }^{14}$ Furthermore, Baraza et al., included only female patients. ${ }^{11}$ Patti et al., included only patients with anterior anal fissures who had raised anal resting pressures. In addition to BTA and fissurectomy they performed a concomitant V-Y anal advancement flap. ${ }^{16}$

In comparison to previous publications, our study has the largest number of patients, the longest follow-up and a standardised dose of BTA. Furthermore, we utilised fissurectomy and BTA injection as a first line therapy for 27 patients who had signs of chronicity without trying topical therapy first as we believe that this group of patients are less likely to respond to topical therapy and even if the fissure heals completely most patients remain symptomatic from the associated signs of chronicity.

The dose of BTA used in previously conducted studies in combination with fissurectomy, varied between 10 and 100 units (Table 2). In this study, a higher dose (100 U) of BTA was consistently used in all patients. The optimum dose of BTA is under debate, however, there is 
suggestion in the literature that the healing rate is dose dependent with no significant difference in the rate of incontinence between doses in the studies. ${ }^{26-30}$

There is considerable variation in the literature in regards to the most effective site of BTA injection. ${ }^{10-17}$ In this study we achieved good outcomes by injecting the BTA into the exposed internal sphincter at the fissure base. We believe this enabled accurate injection of BTA directly into the internal sphincter. Injecting into the exposed sphincter at the fissure base may reduce local complications such as thrombosis, haematoma or sepsis as the sphincter is already exposed.

Our results compare favourably to published data. Ninety-five percent of the enrolled patients achieved resolution of symptoms and complete healing of the fissure(s). Only 5\% needed surgical PLIS or anal advancement flap.

No recurrence was encountered after achieving complete healing in all included patients. This may be due to our approach in ensuring complete mucosal healing and not to accept symptomatic improvement alone as a successful outcome. All patients were counselled thoroughly with great emphasis placed on the need to avoid constipation and the value of a high fibre diet. Bulk forming laxatives were supplied for 8-weeks and patients were advised to take fibre supplements long-term.

Seven patients $(7 \%)$ in our study reported a degree of incontinence in the immediate postoperative period. This appears to be on the upper limit of the range reported (4\%-7\%) in previous studies. ${ }^{3,11-17}$ It is unclear whether the higher dose of BTA we used is to blame for this. Nevertheless, the incontinence in those 7 patients was transient and all patients reported normal continence by the 12-week follow-up.

Our study shows that our policy of using fissurectomy in combination with high dose BTA alone or followed by topical therapy or repeat BTA, if required, is a safe, effective and durable treatment for chronic anal fissure. By adopting this approach, we were able to achieve an overall healing rate of $95 \%$ without resorting to surgical sphincterotomy. There were no recurrences in a mean follow-up period of 33 months, a figure comparable to PLIS.

Our study is limited by the fact that the dose of BTA used was empirical and based on the common doctrine that the higher the dose, the better the outcome therefore we used the highest dose reported in the literature to date, but we did not perform a dose-response study. At the 12-month telephone interview, no physical examination was conducted. All our patients were entirely asymptomatic. Hence, we surmised no recurrence. Furthermore, on final record review none of our patients had received a fissure-related treatment in the three hospitals that serve our county. However, it is possible that some patients may have moved to another area or sought medical management elsewhere. 


\section{Conclusion}

Fissurectomy combined with high dose BTA (100 U) injected directly into the internal sphincter at the fissure base followed by topical diltiazem or repeat BTA, if required, is a safe, effective and durable option for the management of CAF and a promising alternative to surgical sphincterotomy.

The combination of fissurectomy and high dose BTA should be considered the second line therapy for CAF that fails to heal with use of topical therapy or even as a first line therapy for those patients who have signs of chronicity at presentation. The use of our management algorithm curtails the need for surgical sphincterotomy, thereby avoiding the short- and long-term risks of permanent sphincter damage resulting in incontinence.

\section{References}

1. Lund JN, Scholefield JH. Aetiology and treatment of anal fissure. Br J Surg. 1996;83:1335-1344.

2. Zaghiyan KN, Fleshner P. Anal fissure. Clin Colon Rectal Surg. 2011;24:22-30.

3. Lindsey I, Cunningham C, Jones OM, Francis C, Mortensen NJ. Fissurectomybotulinum toxin: A novel sphincter-sparing procedure for medically resistant chronic anal fissure. Dis Colon Rectum. 2004;47:1947-1952.

4. Farouk R, Duthie GS, MacGregor AB, Bartolo DC. Sustained internal sphincter hypertonia in patients with chronic anal fissure. Dis Colon Rectum. 1994;37:424-429.

5. Sileri P, Stolfi VM, Franceschilli L, et al. Conservative and surgical treatment of chronic anal fissure: Prospective longer term results. J Gastrointest Surg. 2010;14:773-780.

6. Cross KLR, Massey EJD, Fowler AL, Monson JRT. The management of anal fissure: Acpgbi position statement. Colorectal Dis. 2008;10 (Suppl. 3):1-7.

7. Perry WB, Dykes SL, Buie WD, Rafferty JF, Standards Practice Task Force of the American Society of C, Rectal S. Practice parameters for the management of anal fissures (3rd revision). Dis Colon Rectum. 2010;53:1110-1115.

8. Casillas S, Hull TL, Zutshi M, Trzcinski R, Bast JF, Xu M. Incontinence after a lateral internal sphincterotomy: Are we underestimating it? Dis Colon Rectum. 2005;48:1193-1199.

9. Nyam DC, Pemberton JH. Long-term results of lateral internal sphincterotomy for chronic anal fissure with particular reference to incidence of fecal incontinence. Dis Colon Rectum. 1999;42:1306-1310.

10. Yiannakopoulou E. Botulinum toxin and anal fissure: Efficacy and safety systematic review. Int J Colorectal Dis. 2012;27:1-9. 
11. Baraza W, Boereboom C, Shorthouse A, Brown S. The long-term efficacy of fissurectomy and botulinum toxin injection for chronic anal fissure in females. Dis Colon Rectum. 2008;51:239-243.

12. Scholz T, Hetzer FH, Dindo D, Demartines N, Clavien PA, Hahnloser D. Long-term follow-up after combined fissurectomy and botox injection for chronic anal fissures. Int J Colorectal Dis. 2007;22:1077-1081.

13. Aivaz O, Rayhanabad J, Nguyen V, Haigh PI, Abbas M. Botulinum toxin a with fissurectomy is a viable alternative to lateral internal sphincterotomy for chronic anal fissure. Am Surg. 2009;75:925-928.

14. Witte ME, Klaase JM, Koop R. Fissurectomy combined with botulinum toxin a injection for medically resistant chronic anal fissures. Colorectal Dis. 2010;12:e163169.

15. Sileri P, Mele A, Stolfi VM, et al. Medical and surgical treatment of chronic anal fissure: A prospective study. J Gastrointest Surg. 2007;11:1541-1548.

16. Patti R, Fama F, Tornambe A, Asaro G, Di Vita G. Fissurectomy combined with anoplasty and injection of botulinum toxin in treatment of anterior chronic anal fissure with hypertonia of internal anal sphincter: A pilot study. Tech Coloproctol. 2010;14:31-36.

17. Arthur JD, Makin CA, El-Sayed TY, Walsh CJ. A pilot comparative study of fissurectomy/diltiazem and fissurectomy/botulinum toxin in the treatment of chronic anal fissure. Tech Coloproctol. 2008;12:331-336; discussion 336.

18. Hayden DM, Weiss EG. Fecal incontinence: Etiology, evaluation and treatment. Clin Colon Rectal Surg. 2011;24:64-70.

19. Garg P, Garg M, Menon GR. Long-term continence disturbance after lateral internal sphincterotomy for chronic anal fissure: A systematic review and meta-analysis. Colorectal Dis. 2013;15:e104-117.

20. Kang GS, Kim BS, Choi PS, Kang DW. Evaluation of healing and complications after lateral internal sphincterotomy for chronic anal fissure: Marginal suture of incision vs. Open left incision: Prospective, randomized, controlled study. Dis Colon Rectum. 2008;51:329-333.

21. Jameson JS, Chia YW, Kamm MA, Speakman CT, Chye YH, MM. H. Effect of age, sex and parity on anorectal function. Br J Surg. 1994;81:1689-1692.

22. Lambe GF, Driver CP, Morton S, Turncock RR. Fissurectomy as a treatment for anal fissures in children. Ann R Coll Surg England. 2000;82:254-257.

23. Aigner F, Conrad F. Fissurectomy for treatment of chronic anal fissures. Dis Colon Rectum. 2008;51:1163; author reply 1164.

24. Nelson R. Non surgical therapy for anal fissure. Cochrane Database Syst Rev. 2003:CD003431.

25. Chen HL, Woo XB, Wang HS, et al. Botulinum toxin injection versus lateral internal sphincterotomy for chronic anal fissure: A meta-analysis of randomized control trials. Tech Coloproctol. 2014.

26. Brisinda G, Maria G, Sganga G, Bentivoglio AR, Albanese A, Castagneto M. Effectiveness of higher doses of botulinum toxin to induce healing in patients with chronic anal fissures. Surgery. 2002;131:179-184.

27. Maria G, Brisinda G, Bentivoglio AR, Cassetta E, Gui D, Albanese A. Botulinum toxin injections in the internal anal sphincter for the treatment of chronic anal fissure: Long-term results after two different dosage regimens. Ann Surg. 1998;228:664-669.

28. Minguez M, Melo F, Espi A, et al. Therapeutic effects of different doses of botulinum toxin in chronic anal fissure. Dis Colon Rectum. 1999;42:1016-1021. 
29. Nelson RL, Chattopadhyay A, Brooks W, Platt I, Paavana T, Earl S. Operative procedures for fissure in ano. Cochrane Database Syst Rev. 2011:CD002199.

30. Nelson RL, Thomas K, Morgan J, Jones A. Non surgical therapy for anal fissure. Cochrane Database Syst Rev. 2012;2:CD003431.

\section{Figure Legend}

Table 1 - Follow up intervals of all patients (hospital record review)

Table 2 - Comparisons of other studies using the combination of fissurectomy and botox

Figure 1 - Overview of the results from our study 


\begin{tabular}{|c|c|}
\hline $\begin{array}{c}\text { Minimum follow-up } \\
\text { (months) }\end{array}$ & $\begin{array}{c}\text { Number of } \\
\text { patients }\end{array}$ \\
\hline 12 & 6 \\
\hline 18 & 13 \\
\hline 24 & 17 \\
\hline 30 & 15 \\
\hline 36 & 16 \\
\hline 42 & 15 \\
\hline 48 & 15 \\
\hline 54 & 5 \\
\hline
\end{tabular}




\begin{tabular}{|c|c|c|c|c|c|c|c|}
\hline $\begin{array}{l}\text { Author } \\
\text { /year }\end{array}$ & $\begin{array}{l}\text { Number } \\
\text { of } \\
\text { patients }\end{array}$ & $\begin{array}{l}\text { Mean } \\
\text { or } \\
\text { median } \\
\text { follow } \\
\text { up in } \\
\text { months } \\
\text { ( } \\
\text { Range) }\end{array}$ & Dose of BTA & $\begin{array}{l}\text { Site of BTA } \\
\text { injection }\end{array}$ & $\begin{array}{l}\text { Healing } \\
\text { rate }\end{array}$ & $\begin{array}{l}\text { Recurrence } \\
\text { rate }\end{array}$ & Complications \\
\hline $\begin{array}{l}\text { Lindsey et al. } \\
(2004)^{5}\end{array}$ & 30 & $\begin{array}{l}4 \\
(2-13)\end{array}$ & $25 \mathrm{U}$ & $\begin{array}{l}\text { Internal } \\
\text { sphincter at the } \\
\text { site of fissure }\end{array}$ & $93 \%$ & $0 \%$ & $\begin{array}{l}\text { 7\% transient } \\
\text { incontinence }\end{array}$ \\
\hline $\begin{array}{l}\text { Scholz et al. } \\
(2007)^{13}\end{array}$ & 40 & $\begin{array}{l}12 \\
(10-18)\end{array}$ & $10 \mathrm{U}$ & $\begin{array}{l}\text { Internal sphincter } \\
\text { on both sides of } \\
\text { fissure }\end{array}$ & $79 \%$ & $9 \%$ or $10 \%$ & $\begin{array}{l}4 \% \text { temporary } \\
\text { incontinence, } 4 \% \\
\text { Abscess }\end{array}$ \\
\hline $\begin{array}{l}\text { Sileri et al. } \\
2007)^{16}\end{array}$ & 22 & $\begin{array}{l}19 \\
(3-33)\end{array}$ & $25 \mathrm{U}$ & $\begin{array}{l}\text { Internal sphincter } \\
\text { at } 3 \text { and } 9 \text { o'clock }\end{array}$ & $82 \%$ & $13.6 \%$ & $\begin{array}{l}4.5 \% \text { temporary } \\
\text { incontinence to } \\
\text { flatus }\end{array}$ \\
\hline $\begin{array}{l}\text { Baraza et al. } \\
(2008)^{12}\end{array}$ & $\begin{array}{l}32 \\
\text { All } \\
\text { females }\end{array}$ & $\begin{array}{l}22 \\
(6-26)\end{array}$ & $25-100 \mathrm{U}$ & $\begin{array}{l}\text { Intersphinteric } \\
\text { space, either side } \\
\text { of fissure }\end{array}$ & $50 \%$ & $50 \%$ & $\begin{array}{l}9 \% \text { local septic } \\
\text { complications } \\
3 \% \text { Urge } \\
\text { incontinence }\end{array}$ \\
\hline $\begin{array}{l}\text { Artur et al. } \\
(2008)^{18}\end{array}$ & 28 & $\begin{array}{l}3 \\
(2-5)\end{array}$ & $40 \mathrm{U}$ & $\begin{array}{l}\text { Internal sphincter } \\
\text { on both sides of } \\
\text { fissure }\end{array}$ & $89 \%$ & NA & $\begin{array}{l}7 \% \text { transient } \\
\text { incontinence }\end{array}$ \\
\hline $\begin{array}{l}\text { Aivaz et al. } \\
(2009)^{14}\end{array}$ & 19 & $\begin{array}{l}19 \\
(1-54)\end{array}$ & $80 \mathrm{U}$ & $\begin{array}{l}\text { Four quadrants of } \\
\text { internal fissure }\end{array}$ & $69 \%$ & $5 \%$ & $0 \%$ \\
\hline $\begin{array}{l}\text { Witte } \text { et al. } \\
(2009)^{15}\end{array}$ & 21 & $\begin{array}{l}16 \\
(9-30)\end{array}$ & $\begin{array}{l}80 \mathrm{U} \text { of } \\
\text { Dysport }\end{array}$ & $\begin{array}{l}\text { Visible internal } \\
\text { sphincter +closure } \\
\text { of fissurectomy } \\
\text { site }\end{array}$ & $90 \%$ & $0 \%$ & $\begin{array}{l}10 \% \text { - Perianal } \\
\text { dermatitis }\end{array}$ \\
\hline $\begin{array}{l}\text { Patti et al. } \\
(2010)^{17}\end{array}$ & $\begin{array}{l}10 \\
\text { All } \\
\text { anterior } \\
\text { fissure }\end{array}$ & $\begin{array}{l}12 \\
(\mathrm{~N} / \mathrm{A})\end{array}$ & $\begin{array}{l}30 \mathrm{U} \\
+ \\
\text { anal } \\
\text { advancement } \\
\text { flap }\end{array}$ & $\begin{array}{l}\text { Internal sphincter } \\
\text { opposite to the site } \\
\text { of fissure }\end{array}$ & $100 \%$ & $0 \%$ & $\begin{array}{l}1 / 10 \text { transient } \\
\text { incontinence } \\
2 / 10 \text { septic } \\
\text { complications } \\
1 / 10 \text { wound break } \\
\text { down }\end{array}$ \\
\hline $\begin{array}{l}\text { Our Study } \\
\text { (2014) }\end{array}$ & 102 & $\begin{array}{l}33 \\
(12-54)\end{array}$ & $100 \mathrm{U}$ & $\begin{array}{l}\text { Internal sphincter at } \\
\text { the base of fissure }\end{array}$ & $95 \%$ & $0 \%$ & $\begin{array}{l}7 \% \text { transient } \\
\text { incontinence. }\end{array}$ \\
\hline
\end{tabular}


Fissurectomy and

Botox treatment

$$
(n=102)
$$

Asymptomatic and discharged

$(n=68)$

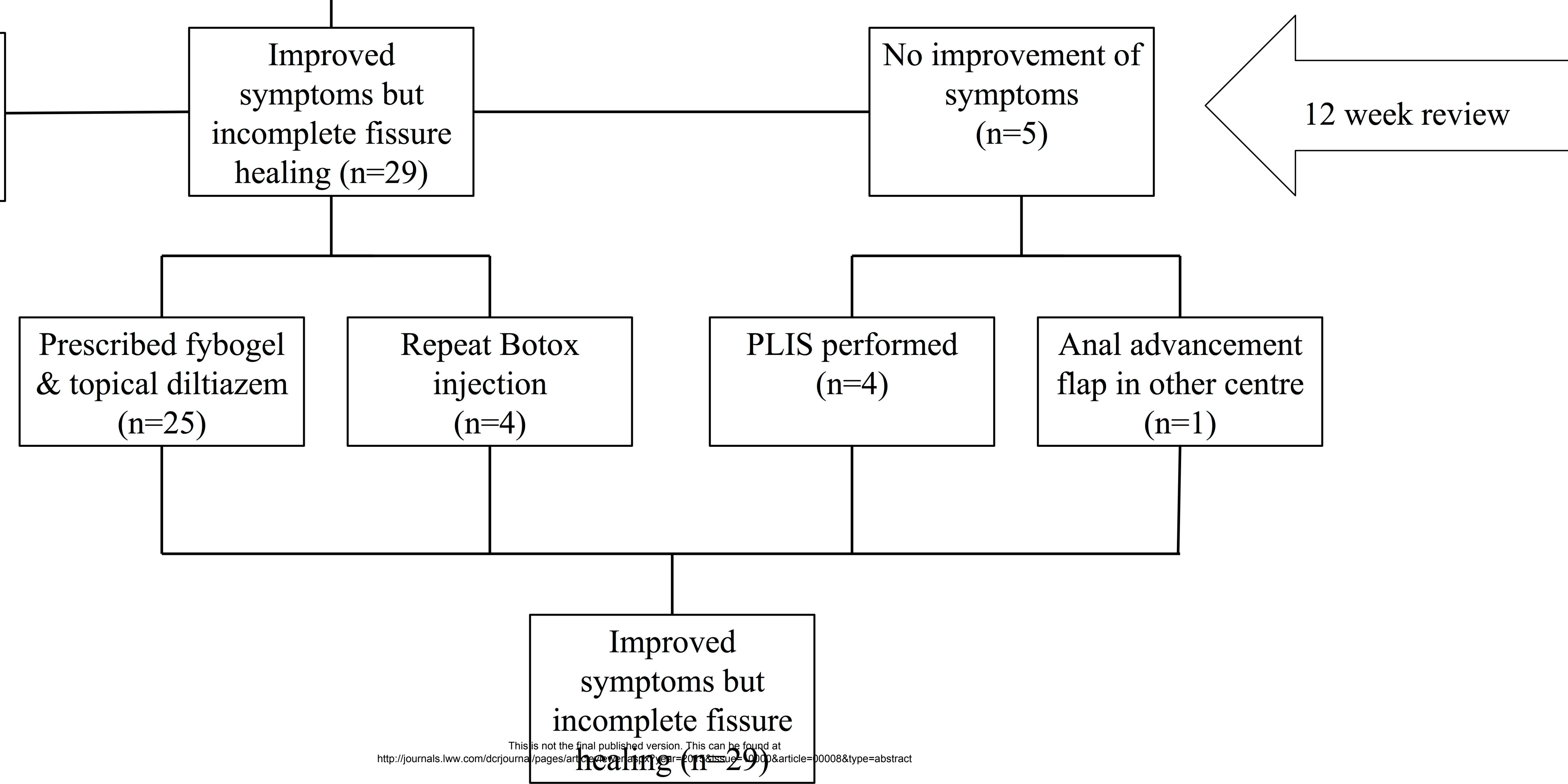

